\title{
Performance of University-Construction Industry Collaboration: A Systematic Literature Review and Research Agenda
}

\author{
Ziad Al-Gasim \\ eaaziad2@graduate.utm.my \\ Azman Hashim International Business School, Universiti Teknologi Malaysia, Johor Bahru, Malaysia \\ Aslan Amat Senin \\ aslan@management.utm.my \\ Azman Hashim International Business School, Universiti Teknologi Malaysia, Johor Bahru, Malaysia \\ Mohd Effandi bin Yusoff \\ effandi@utm.my \\ Azman Hashim International Business School, Universiti Teknologi Malaysia, Johor Bahru, Malaysia
}

\begin{abstract}
University-construction industry collaboration (UIC) has become an essential part of driving innovation and fostering construction industry growth. Measuring performance of such collaboration is an emergent field of study. The present research evaluated the literature related to measuring performance of university-construction industry collaboration taking into consideration the publications in selected scientific databases. Findings were discussed and confirmed in the context of Qatar education and innovation ecosystem through semi-structured interviews with two renowned scholars involved in university-construction industry collaboration. This study aims to (1) identify the most cited references in measuring UCIC performance (2) identify UIC performance indicators advocated by top cited references, and (3) refine and map UIC performance indicators in the context of the state of Qatar. The publications reviewed were obtained through a search of the Science Direct, Emerald Insight, Scopus, Web of Science, Springer Link, SAGE, Research Gate, and Taylor \& Francis Online. Keywords used in searching for articles included university-construction industry, university-construction business, cooperation, collaboration, relation, performance, and measurement. The study revealed that universities are increasingly focused on measuring performance of collaboration with construction industry. As such, it contributes to a general understanding of measuring UIC performance and defining trends in this research field. It also highlights specifically the challenges for measuring UIC performance in Qatar. In this context, key UIC performance indicators include (1) Number of Publications, (2) Number of Citations (3) Number of Registered Patents, (4) Number of Patent Applications, (5) Number of Training Programs Provided and (6) Number of Innovations.
\end{abstract}

Keywords: University; Industry; Construction; Cooperation; Collaboration

\section{INTRODUCTION}

In the age of cyberspace, machine learning, and artificial intelligence, competition has become fierce for universities as well as for construction industry and business actors. Companies are expected to surpass competitors through developing innovative products and services, satisfying customers' requirements, showing business agility, and rapidly 
responding to market demands (Ivascu et al., 2016). Universities on the other hand are competing for social reputation and academic excellence in order to attract resources invested in contribution to knowledge and capacity building of the future (Striukova \& Rayna, 2015).

A closer look at the economies of developed countries reveals that their innovation level is the result of knowledge creation and its application in industries, which contributes to achieving competitive advantages (Mascarenhas et al., 2018). Therefore, innovation has become a key focus for universities as well as for industry and business actors. However, none of these actors has all skills and resources required to foster innovation agenda. As a result, it is expected to see collaboration for mutual benefits between actors of the innovation ecosystem (Chesbrough, 2012).

University and construction industry can cooperate in different ways. They include, but not limited to, research and development, mobility of academics, mobility of students, commercialization of research results, curriculum development, curriculum delivery, lifelong learning, spinoff and startup formation, and university governance. Davey et al. (2011) found that types of university-industry cooperation that provides straight and measurable benefits having tendency to be the most developed types of cooperation, e.g., research and development, commercialization, and student mobility. Thus, universityindustry collaboration, shortly termed "UIC", can take several forms and practice through various activities. Commonly, such collaboration falls under one of three main activities: (1) collaborative training and education, (2) collaborative consulting and services, and (2) collaborative research (Ishengoma \& Vaaland, 2016) (Vaaland \& Ishengoma, 2016) (Galán-Muros et al., 2017) (Davey et al., 2011).

Indeed, outcome of such collaborations is realized differently by universities and industry. From university perspective, such outcomes are realized by aspects related to enhanced learning environment, increased rates of knowledge creation, and better serving society and regional economies. From the industry perspective, such outcomes are realized by aspects related to improved innovation rates, revenues, and access to resources (Berbegal-Mirabent et al., 2015; D'este \& Perkmann, 2011)

Accordingly, UIC is essential to establish and nurture innovation ecosystems that drive country innovation agenda and sustain economic growth (Etzkowitz, 2017). In United States, the notable program to drive UIC is through Bayh-Dole Act (1980) (Hall, 2004). The comparable program in Europe is the Horizon 2020 (Mascarenhas et al., 2018). In Qatar, UIC is driven mainly by the Qatar National Research Fund (QNRF) (Foundation, 2015).

However, the economic dynamic between two major actors of innovation ecosystem faces a dilemma. It consists of two distinguished economies: the knowledge economy and commercial economy. The first is driven by a need for advanced fundamental research or social value through universities and research centers, while the second is driven by the requirements of the marketplace that should be satisfied by business entities (Jackson, 2011). Such dilemma makes measuring UIC performance a challenge for university and construction industry alike.

Indeed, there is a vast literature on the topic of UIC. Additionally, few studies have conducted a systematic literature review to present propositions, findings, and research trends in the field. However, these studies have focused on aspects related to technology 
transfer (Agrawal, 2001), UIC governance (Geuna \& Muscio, 2009), commercialization (Perkmann et al., 2013), collaboration forms or activities (Rothaermel et al., 2007), university entrepreneurship, and UIC as open innovation (Mascarenhas et al., 2018).

To the best of our knowledge, literature does not include any systematic literature review (SLR) on the subject matter of measuring performance of university-industry relations. Therefore, this research sought to fill this gap in the area and review most relevant literature on measuring performance of UIC. We also conducted semi-structured interviews in order to refine, align, and interpret SLR findings in the context of the State of Qatar.

Therefore, this research, in one hand, contributes to systematic literature review focused on UIC performance. On the other hand, it sheds light on policy and contextrelated matters for UIC performance in Qatar. In this sense, this research presents a future research agenda for measuring UIC performance. This study aims to (1) identify the main cited references in measuring UIC performance, (2) identify UIC performance matrices advocated by top cited references, and (3) refine performance matrices of UIC in the context of the State of Qatar.

The published articles reviewed were obtained through a search of the Science Direct, Emerald Insight, Scopus, Web of Science, Springer Link, SAGE, Research Gate, and Taylor \& Francis Online databases. Keywords used in searching for published articles were university-industry, university-business, cooperation, collaboration, relation, performance, and measurement. Findings are discussed and confirmed in the context of Qatar innovation and education ecosystem through semi-structured interviews with two renowned scholars involved in university-industry collaboration.

The rest of the article is structured as follows: Section 2 provides an overview of methodology used in literature review, Section 3 presents and discusses results, Section 4 presents limitations and recommendations for future research, and finally Section 5 concludes the whole paper.

\section{METHODOLOGY}

A systematic review of the available academic research was carried out on the topic of UIC. The search for published articles was carried out in Science Direct, Emerald Insight, Scopus, Web of Science, Springer Link, SAGE, Research Gate, and Taylor \& Francis Online. We used keywords in searching for articles including universityindustry, university-business, cooperation, collaboration, relation, performance, and measurement. Published articles reviewed with 15 years of temporal restriction, i.e., articles published since 2004. This restriction was chosen to reveal most recent trends in this emergent field of research. The temporal selection was also in line with the coverage limitation of Scopus databases, as it is currently limited to articles published since 1995 (Mascarenhas et al., 2018). In addition, top cited articles, e.g., the work of (Agrawal, 2001), were also considered, beyond the temporal restrictions, when repeatedly cited in most recent articles.

The literature research was performed on the period between 10/02/2018 and 10/08/2019. The literature research followed six steps as displayed in Figure 1 below. In parallel, the researcher reached out to two active scholars in university-industry collaboration from Qatar University. The researcher conducted semi-structured 
interviews with both scholars in order to reveal country-specific concerns, challenges, and priorities in regard to measuring UIC performance (AlMadeed, 2019; Ben-Ayed, 2018). The interviews were conducted on 19-02-2018 and 07-01-2019. The semistructured interviews protocol is displayed in Figure 2 (Saunders \& Lewis, 2012).

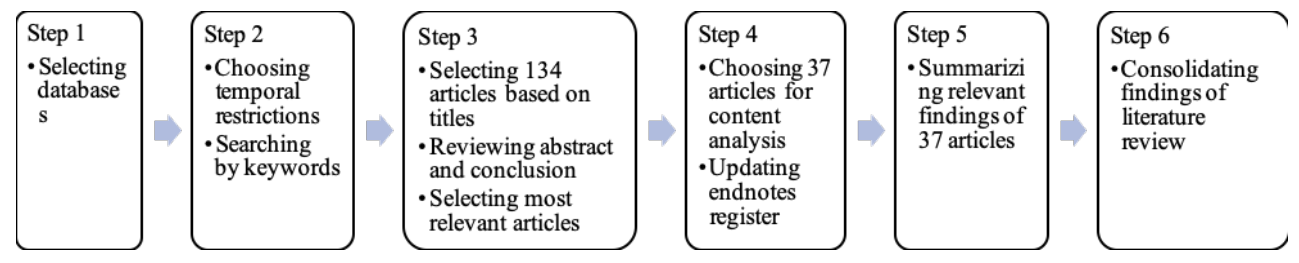

Figure 1: Steps Followed in Literature Research

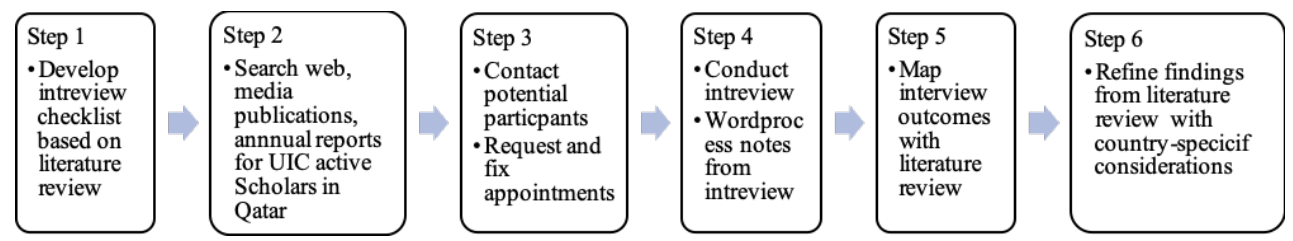

Figure 2: Steps Followed in Conducting Semi-Structured Interviews

\section{RESULTS}

\subsection{Overview of Selected Publications for Content Analysis}

In step 4 of the literature review, 37 published articles were selected for content analysis, which included mainly articles in the last 15 years with more focus on most recent publications, as shown in the Figure 3.

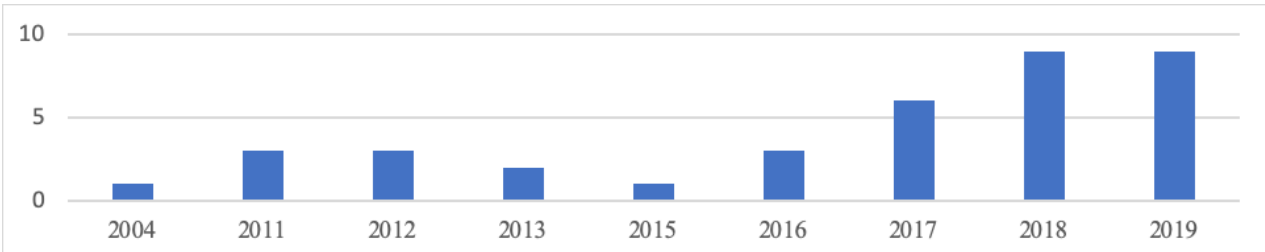

Figure 3: Publication Year of the Selected Articles for Content Analysis

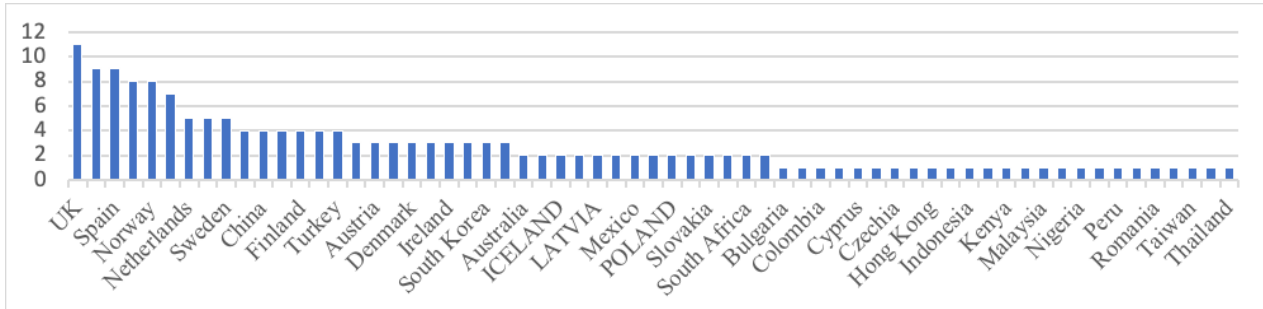

Figure 4: Context of Selected Papers for Content Analysis

From the context perspective, the selected articles covered 63 countries with more articles published in the European context, as shown in the Figure 4. A review of literature published during the last 15 years showed the absence of research related to measuring 
UIC performance in Gulf Cooperation Council countries (GCC) and Qatar. This issue provided more rational to conduct interviews and refine findings according to countryspecific considerations.

\subsection{UIC Performance Explained}

University-industry relations influence all three institutional logics involved, i.e., university, industry, and cooperation or collaborative forms of organizing. (Hue Kyung et al., 2016) studied the relationships between the competence factors of universities and the university-industry cooperation performance. Their findings suggested significant influence of university research capacity on driving performance of the UIC in terms of providing full-time faculty members and the size of the Technical Licensing Office (TLO). Hue Kyung et al. (2016) argued that performance in this case is mediated by government funding for research and development activities.

Similarly, Rajalo and Vadi (2017) argued the role of Technology Transfer Offices (TTOS) in establishing successful university-industry partnerships. First, they studied the relationships between TTO age, TTO staff in R\&D contracts, and TTO budget with R\&D contracts in terms of number and income size. Then, they studied the impact of having a science park on R\&D contracts in terms of number and income. Their findings suggested a positive relation between TTO experience and annual budget as well as availability of science parks with income and number of R\&D contracts. Another important factor argued by (Rajalo \& Vadi, 2017) was the positive influence of university social-capital on setting R\&D contracts. Universities with larger social networks, both local and international, are more successful in attracting R\&D contracts.

The technology parks influence on university and industry performance differs based on university involvement and its share in the park. For that reason, (Albahari et al., 2017) distinguished four types of parks. The first type, where university is the major shareholder, is called Pure Science Park. The second type, where university is the minority shareholder, is called Mixed Park. The third type, where some university research facilities are located in the park, but university holds no share, is called Technology Park. The fourth type, where the university has no formal involvement is called Pure Technology Parks. Their research findings suggested that the higher involvement of the university, in case of the Pure Science Parks, is correlated with best patenting performance among universities. Unlikely, such involvement is correlated with the lowest product innovation levels measured by sales from new to the market products. On the other side of the spectrum, it was suggested that the lowest involvement of the university, in case of the Pure Technology Parks, is correlated with the lowest patenting performance among universities. On the contrary, such involvement is correlated with best product innovation levels measured by sales from new to the market products. Yet there is no evidence that chance of cooperation between universities and industry, in case of research contracts, is influenced by the degree of university involvement in park shareholding.

Therefore, high level of patent applications and potentially published research, in case of pure science parks does not necessarily lead to increased product innovation. On the other hand, a high level of product and innovation in case of pure technology parks is not necessarily associated with high level of patent applications, nor publication 
of studies. These findings illustrate different interest dilemma in university-industry relations. Albahari et al. (2017) suggested that changes to academic reward system shift the academic focus from publishing and patenting to inclusion of commercialization.

Indeed, Muscio et al. (2012) expressed the extent of university-industry collaboration success in terms of capability to attract funding for research activities. He suggested three important elements that can improve such capability. First, previous experience with the business, which builds on recent studies conducted by (Bstieler et al., 2017) regarding the relationship maturity and trust building. Second, ability to produce critical mass of research in a certain sector, which builds on previous studies conducted by (Anatan, 2015) regarding the institutional pressure to improve performance of the university in research activities. And third, the proximity to industrial districts, which build on previous studies conducted by (Villani et al., 2017) regarding different types of distances between university and industry partners, including cognitive, geographical, organizational, and social distances.

The influence of publicly-funded university-industry collaboration on research and development efforts by the industry was investigated by (Scandura, 2016). His findings provided interesting insights into the construction industry. First, universityindustry partnerships have a positive impact on the $R \& D$ expenditure per employee. Second, university-industry partnerships have a positive impact on the share of R\&D employment. In fact, the partnership between university and industry not only enhances the resource utilization for the construction industry, but also encourages the industry to invest more in research and development activities.

University-industry relation is a two-way relationship. Thus, reflection on performance is realized on both sides of the relationship. This is a major outbreak from the traditional role of university knowledge transfer, i.e., a one-way relationship. Striukova and Rayna (2015) investigated the adoption of the open innovation concept by universities. The rise of open innovation in the industry contributed to a "changed paradigm" with respect to university-industry relations. Their findings, in context of UK universities, revealed that universities become a central actor in open innovation ecosystems through acting as reliable intermediary or open innovation hub. This role contributes to performance of both the university and other actors in the ecosystem. Striukova and Rayna (2015) also highlighted the diversity of the institutional logic among universities in terms of norms, values, cultures, and management structures. This, in turn, provides diverse reactions, motivations, and attitudes towards implementation of open innovation.

Similarly, Huang and Chen (2017) studied how to improve academic innovation performance in university-industry collaboration. His findings suggested a positive relationship between both formal management mechanisms and regulation implementation, and academic innovation performance. Both relationships were found to be moderated by the university innovation climate. In this context, formal management mechanism for university-industry relations is related to formal arrangements to control and coordinate university-industry relations under the subject of university. Regulation implementation is related to implementation of specific regulations to foster research and development as well as university-industry relations. Finally, innovation atmosphere reflects the university support for entrepreneurial activities by faculty members, students, and administration staff. 
Similarly, in a recent study conducted in Europe, (Galán-Muros et al., 2017) found a positive relationship between four management mechanisms and seven key activities of university-business collaboration. The mechanisms were top management support, communication, incentives, and support structures. The seven key collaboration activities were joint curriculum design and delivery, lifelong learning, student mobility, professional mobility, joint $R \& D$, entrepreneurship, and $R \& D$ commercialization of joint $R \& D$ results.

Also Perkmann et al. (2013) investigated the role of academic engagement in sustaining university-industry relations. Academic engagement refers to knowledge-related collaboration activities by researchers with industry and non-academic organizations. Perkmann et al. (2013) also distinguished the determinants that lead to academic commercialization from determinants of academic engagement. Commercialization refers to the use of knowledge created by university through patenting, licensing of inventions, and business entrepreneurship. Their findings suggest a positive relationship between some individual determinants and academic engagement. These determinants include gender (male), seniority, previous grant experience from government, previous contract experience from industry, and scientific productivity. In the same sense, Davey et al. (2011) found that academic age (seniority), gender (male), previous business experience, and technology orientation are among the key individual drivers of university-industry relations.

Moreover, Perkmann et al. (2013) argued that some other organizational and institutional determinants positively moderate the relationship between individual determents and academic engagements. These include university focus on applied disciplines. Surprisingly, they debated that quality of the university or department concerned has a negative influence on academic engagement. This finding may be justified by the fact that lower quality departments often have less resources and more reasons to seek engagements and collaborations with the industry.

In addition, Perkmann et al. (2013) asserted that commercialization has a positive relationship with individual determinants, which include gender (male), previous commercialization experience, and scientific productivity. Similarly, some other institutional determinants positively moderate the relationship between individual determinants and academic commercialization. These include quality of the university or department concerned, organizational support, organizational commercialization experiences, peer effects, university focus on applied disciplines, and country specific regulatory policies. Likewise, they argued that academic commercialization often leads to increased secrecy and scientific productivity among academics. Finally, academic engagement often leads to improved collaborative behavior (Corral de Zubielqui et al., 2015).

It should be noted that previous funding experience of academics can be a result of previous none-academic experience. Thus, Gulbrandsen \& Thune, 2017 studied the impact of prior none-academic work experience on both external interactions and academic performance. The external interaction in their study refers to activities of dissemination of knowledge, research collaboration, commercialization, and training activities. Academic performance refers to measures of research quality that is represented by publication in highly ranked journals, and research productivity represented by 
number of publications. According to their findings, non-academic work experience positively influences external interaction activities among academics. In addition, there was no evidence to suggest that non-academic work experience has a negative effect on academic performance.

To acquire and share knowledge is a key to both university and industry, especially in regard to patenting and licensing new technologies (Azagra-Caro et al., 2017; Clauss $\&$ Kesting, 2017). Indeed, university-industry relations influence the performance and outcomes of both institutional logics. From the university side, the intended outcomes include attraction of third-party fund for employees, research, and operational expenses, research papers published, conferences, presentations, and reputation gains among scientific community. From the business side, the intended outcomes include new inventions in products, services and processes, new licenses, and new patents (Clauss \& Kesting, 2017).

However, Clauss and Kesting (2017) took into consideration the control factors to examine the impact of knowledge sharing on achieving the objectives of UIC. These control factors include obligation to get external research funding (Goel et al., 2017), professors' attitude towards university-industry collaborations (Lam, 2010), the degree of applied research (OECD, 2002), the number of employees under professors' supervision, professors' years of experience, size of partner organization, and type of partner organization whether it is a private company, public organization, or not-forprofit organization.

Furthermore, relational governance energizes the performance of university-industry relations. Academics and industry counter partners are individuals whose culture, attitudes, behaviors, and mutual experience influence their relationships. The influence can be on issues such as the relationship form, sustainability, and future expectations. In this case, ideas are openly shared, and knowledge is voluntarily combined and created by partners from both institutional logics. Likewise, Davey et al. (2011) maintained that university-industry cooperation is a people business that demands constant dialogue and building of social networks. Consequently, they argued that activities aimed at promoting UIC should focus on improving relationships, commitment, and trust between academics and business. They also believed that focus on transactional mechanisms such as patenting and licensing has a negative influence on building the sense of trust, commitment, and sharing goals among individuals involved in UIC.

\subsection{Summary of Key UIC Performance Indicators}

Definitions of all performance indicators identified in the content analysis were reviewed, refined, and grouped in order to provide list of distinct indicators, avoid duplications, and remove repetitions. Moreover, measuring UIC performance can take place from university or industry perspectives. Therefore, the performance indicators from each perspective were grouped into two separate lists.

From university perspective, literature review revealed 26 indicators to measure UIC performance. So from university perspective, the most frequent UIC performance indicators include (1) Number of Publications, (2) Number of Registered Patents, (3) Number of Generated Startups \& Spinoffs, (4) Income from IP Sales, (5) Number of Patent Applications, (6) Income by type of UIC Activity (Consulting \& Services, Research, and 
Training \& Education), (7) Number of IP Licenses, (8) Number of Occurrences for each UIC Activity (Consulting \& Services, Research, and Training \& Education), and (9) Impact Factor of Publications.

From industry perspective, literature review revealed 21 indicators to measure UIC performance. So from industry perspective, the most frequent UIC performance indicators include (1) Number of Innovations (Process/Marketing/Product/Organizational), (2) Number of Registered Patents, (3) Income from Innovations (Process/Marketing/ Product/Organizational), (4) Number of Patent Applications, (5) Number of Joint Publications, (6) Number of Postgraduate Positions offered within UIC, (7) Number of Joint Supervision to Postgraduate Students, (8) Number of Occurrences for each UIC Activity (Consulting \& Services, Research, and Training \& Education), and (9) Number of IP Licenses.

Indeed, the above results show different focus for university and industry when measuring UIC performance. These findings are in line with initial discussion stating that universities and industries often operate in different institutional logics (David \& van der Sijde, 2015) (Striukova \& Rayna, 2015). However, the above results show that both university and industry share some interest when it comes to three key performance indicators. These indicators are (1) Number of Registered Patents, (2) Number of Patent Applications, and (3) Number of IP Licenses. These finding suggests that at the core of mutual benefit foreseen from university-industry relations is driving innovation (Lašáková et al., 2017).

\subsection{UIC Performance Indicators and Context-Specific Considerations}

The two conducted interviews revealed interesting findings with respect to measuring UIC performance from perspective of Qatar University. In order of significance, both interviews highlighted key indicators to measure UIC performance including (1) Number of Publications, (2) Number of Citations (Local and International), (3) Number of Registered Patents, (4) Number of Registered Applications, (5) Number of Training Programs Provided (to Faculty and Students), and (6) Number of Innovations (Process/ Product). (AlMadeed, 2019) (Ben-Ayed, 2018).

The above findings, at least from the interviewees' perspective, provide some key context-specific considerations. In one hand, number of publications, patent registrations, and applications as top UIC performance indicators are in line with previous findings provided by previous literature (Azagra-Caro et al., 2019; Castro et al., 2019; Chen et al., 2019). On the other hand, number of citations is related to previous indicators obtained from literature including citation index (Perkmann et al., 2011) and impact factor of publications (Van Looy et al., 2004); (Aldieri et al., 2018) (Gulbrandsen \& Thune, 2017).

Moreover, the indicator of number of innovations (process/product) is also related to previous indicators obtained from literature including number of innovations (process/ marketing/product/organizational) (Chen et al., 2019; Von Raesfeld et al., 2012). However, the high importance of this indicator, from the interviewees' perspective, may be related to directions of Qatar National Research Strategy (QNRS) (Fund, 2012) that is aimed at putting Qatar in the world map as a research and innovation hub (Ministry of Development, 2018) (Planning, 2008).

Another interesting finding is the indicator of Number of Training Programs Provided 
(to Faculty and Students). From both university and industry perspectives, this indicator is related to Number of Occurrences for each UIC Activity (Rajalo \& Vadi, 2017; Clauss \& Kesting, 2017; Hue Kyung et al., 2016; Berbegal-Mirabent et al., 2015). The UIC activity in this case is collaborative Training \& Education (Ishengoma \& Vaaland, 2016) (Vaaland \& Ishengoma, 2016).

Historically, university-industry relations have been viewed as means to transfer knowledge from the knowledge economy, i.e., universities, to the commercial economy, i.e., industry and business (Jackson, 2011). As a result, the later indicator may suggest that the interviewees look to industry relations also as means to transfer back knowledge and technology from industry to university members (Paavola \& Hakkarainen, 2005) (Etzkowitz, 2017).

In fact, none of the performance indicators obtained from interviews is related to commercialization and revenue generations of university-industry relations. These findings are in contradiction with top UIC performance indicators obtained from literature in relation to Number of Generated Startups \& Spinoffs (Castro et al., 2019), Number of and Income from IP Sales (Son et al., 2019; Rossi \& Rosli, 2013), Number of and Income by type of UIC Activity (Consulting \& Services, Research, and Training \& Education) (Rajalo \& Vadi, 2017; Clauss \& Kesting, 2017). Therefore, a deeper look into motives and drivers of the Qatar National Research Strategy (QNRS) (Fund, 2012) is needed in future research.

\section{LIMITATIONS AND FUTURE RESEARCH}

This study is limited to a 15-year span of time and publication databases used for searching papers. The key words used in this research provided another limitation to number of generated papers by selected publication databases. Thus, it is recommended for future research to consider a wider literature search in terms of time span, publication databases, and key words.

In addition, only two interviews were conducted with active scholars in universityindustry relations. The objective of conducting interviews was to map and refine the findings of literature review with country-specific considerations. Furthermore, both interviews were conducted with scholars from Qatar University. None of the interviewees comes from industry and businesses. Therefore, mapping and refining indicators and country-specific considerations from industry perspective was not possible. Consequently, it is recommended to future researchers to consider a wider representation of scholars and business leaders engaged in university-industry relations in Qatar, or any other context of interest, to get insights that further enable refinement and mapping of findings from literature.

Indeed, this research was mainly a literature review, and country specific considerations were obtained from limited number of interviews. Therefore, results are yet to be confirmed empirically in the context of Qatar. Comparative analysis of UIC performance indicators used across countries is another attractive field for future research.

\section{CONCLUSION}

First, this study revealed that universities are increasingly focused on measuring 
performance of collaboration with industry. The results offered a number of UIC performance indicators, including (1) Number of Publications, (2) Number of Registered Patents, (3) Number of Generated Startups \& Spinoffs, (4) Income from IP Sales, (5) Number of Patent Applications, (6) Income by type of UIC Activity (Consulting \& Services, Research, and Training \& Education), (7) Number of IP Licenses, (8) Number of Occurrences for each UIC Activity, (9) Impact Factor of Publications, and (10) Number of Innovations (Process/Marketing/Product/Organizational).

Second, this study revealed that industry is increasingly focused on measuring performance of collaboration with university. The results presented a number of UIC performance indicators, including (1) Number of Innovations (Process/Marketing/ Product/Organizational), (2) Number of Registered Patents, (3) Income from Innovations (Process/Marketing/Product/Organizational), (4) Number of Patent Applications, (5) Number of Joint Publications, and (6) Number of Postgraduate Positions offered within UIC.

Third, university and industry share common interests when it comes to driving innovations as a key motive for university-industry relations. This proposition is supported by the common interests in measuring UIC performance through (1) Number of Innovations (Process/Marketing/Product/Organizational), (2) Number of Registered Patents, and (3) and Number of Patent Applications.

Fourth, this study thus contributes to a general understanding of measuring UIC performance and trends in this emergent field of research. It also highlights the Qatar country-specific considerations and challenges for measuring UIC performance considerations. In such context, the key UIC performance indicators are (1) Number of Publications, (2) Number of Citations (Local and International), (3) Number of Registered Patents, (4) Number of Registered Applications, (5) Number of Training Programs Provided (to Faculty and Students), and (6) Number of Innovations (Process/ Product).

Fifth, there is also a need for more research examining a wider range of performance indicators, impacts of research strategies, and related policies. In Qatar, in particular, there is a lack of empirical studies concerning the effects of the Qatar National Research Strategy (QNRS) (Fund, 2012) and impact on what indicators to choose and monitor for UIC performance.

In conclusion, despite numerous studies conducted on measuring performance of UIC, there is still a great deal of research yet to be conducted in order to model, theorize, and empirically test the indicators used to measure UIC performance, in general, and in context of the State of Qatar, in particular.

\section{REFERENCES}

Agrawal, A. K. (2001). University-to-industry knowledge transfer: Literature review and unanswered questions. International Journal of management reviews, 3(4), 285-302.

Al-Ashaab, A., Flores, M., Doultsinou, A. \& Magyar, A. (2011). A balanced scorecard for measuring the impact of industry-university collaboration. Production Planning \& Control, 22(5-6), 554-570.

Albahari, A., Pérez-Canto, S., Barge-Gil, A. \& Modrego, A. (2017). Technology Parks versus 
Science Parks: Does the university make the difference? Technological Forecasting and Social Change, 116, 13-28.

Albats, E., Fiegenbaum, I. \& Cunningham, J. A. (2018). A micro level study of university industry collaborative lifecycle key performance indicators. The Journal of Technology Transfer, 43(2), 389-431.

Aldieri, L., Kotsemir, M. \& Vinci, C. P. (2018). The impact of research collaboration on academic performance: An empirical analysis for some European countries. Socio-Economic Planning Sciences, 62, 13-30.

AlMadeed, D. M. (2019). University-Industry Relations. In Z. Al-Gasim (Ed.), VP of Research \& Graduate Studies - Qatar University, Doha.

Anatan, L. (2015). Conceptual issues in university to industry knowledge transfer studies: a literature review. Procedia-Social and Behavioral Sciences, 211, 711-717.

Ankrah, S. \& Omar, A.-T. (2015). Universities-industry collaboration: A systematic review. Scandinavian Journal of Management, 31(3), 387-408.

Ávila, L. V., Leal Filho, W., Brandli, L., Macgregor, C. J., Molthan-Hill, P. \& Özuyar, P. G., et al. (2017). Barriers to innovation and sustainability at universities around the world. Journal of cleaner production, 164, 1268-1278.

Azagra-Caro, J. M., Barberá-Tomás, D., Edwards-Schachter, M. \& Tur, E. M. (2017). Dynamic interactions between university-industry knowledge transfer channels: A case study of the most highly cited academic patent. Research Policy, 46(2), 463-474.

Azagra-Caro, J. M., Tijssen, R. J., Tur, E. M. \& Yegros-Yegros, A. (2019). University-industry scientific production and the Great Recession. Technological Forecasting and Social Change, 139, 210-220.

Babić, V. \& Savović, S. (2018). University characteristics as the success factor of academic spinoffs. Zbornik Ekonomskog fakulteta u Zagrebu, 16(1), 113-127.

Battaglia, D., Landoni, P. \& Rizzitelli, F. (2017). Organizational structures for external growth of university technology transfer offices: an explorative analysis. Technological Forecasting and Social Change, 123, 45-56.

Ben-Ayed, P. O. (2018). University-Industry Relations. In Z. Al-Gasim (Ed.), Department of Management and Marketing - Qatar University, Doha.

Berbegal-Mirabent, J., García, J. L. S. \& Ribeiro-Soriano, D. E. (2015). University-industry partnerships for the provision of R\&D services. Journal of Business Research, 68(7), 14071413.

Bstieler, L., Hemmert, M. \& Barczak, G. (2017). The changing bases of mutual trust formation in inter-organizational relationships: A dyadic study of university-industry research collaborations. Journal of Business Research, 74, 47-54.

Castro, I. J. D., Nagano, M. S. \& Ribeiro, S. X. (2019). Elements that influence knowledge sharing in the university-industry-government collaboration: Case studies in Brazil. Revista de Gestão, 26(1), 61-72.

Chen, G., Yang, G., He, F. \& Chen, K. (2019). Exploring the effect of political borders on university-industry collaborative research performance: Evidence from China's Guangdong province. Technovation, 82, 58-69.

Chesbrough, H. (2012). Open innovation: Where we've been and where we're going. ResearchTechnology Management, 55(4), 20-27. 
Clauss, T. \& Kesting, T. (2017). How businesses should govern knowledge-intensive collaborations with universities: An empirical investigation of university professors. Industrial Marketing Management, 62, 185-198.

Corral de Zubielqui, G., Jones, J., Seet, P.-S. \& Lindsay, N. (2015). Knowledge transfer between actors in the innovation system: a study of higher education institutions (HEIS) and SMES. Journal of Business \& Industrial Marketing, 30(3/4), 436-458.

D'este, P. \& Perkmann, M. (2011). Why do academics engage with industry? The entrepreneurial university and individual motivations. The Journal of Technology Transfer, 36(3), 316-339.

Dalmarco, G., Hulsink, W. \& Blois, G. V. (2018). Creating entrepreneurial universities in an emerging economy: Evidence from Brazil. Technological Forecasting and Social Change, $135,99-111$.

Davey, T., Baaken, T., Galan Muros, V. \& Meerman, A. (2011). The State of European UniversityBusiness Cooperation. Part of the DG Education and Culture Study on the cooperation between higher education institutions and public and private organisations in Europe, 140.

David, F. \& van der Sijde, P. (2015). University-Business Co-operation in Indonesian Higher Education for Innovation. In New Technology-Based Firms in the New Millennium (pp. 187200): Emerald Group Publishing Limited.

Etzkowitz, H. (2017). Innovation Lodestar: The entrepreneurial university in a stellar knowledge firmament. Technological Forecasting and Social Change, 123, 122-129.

Fischer, B. B., Schaeffer, P. R., Vonortas, N. S. \& Queiroz, S. (2018). Quality comes first: university-industry collaboration as a source of academic entrepreneurship in a developing country. The Journal of Technology Transfer, 43(2), 263-284.

Foundation, Q. (2015). Qatar Foundation Annual Report_2014-15. Doha - (Qataro. Document Number).

Franco, M. \& Haase, H. (2015). University-industry cooperation: Researchers' motivations and interaction channels. Journal of Engineering and Technology Management, 36, 41-51.

Fund, Q. N. R. (2012). Qatar National Research Strategy 2012. Doha: Qatar National Research Fund. (Q. N. R. Fund o. Document Number).

Galán-Muros, V., van der Sijde, P., Groenewegen, P. \& Baaken, T. (2017). Nurture over nature: How do European universities support their collaboration with business? The Journal of Technology Transfer, 42(1), 184-205.

Garcia-Perez-de-Lema, D., Madrid-Guijarro, A. \& Martin, D. P. (2017). Influence of universityfirm governance on SMEs innovation and performance levels. Technological Forecasting and Social Change, 123, 250-261.

Geuna, A. \& Muscio, A. (2009). The governance of university knowledge transfer: A critical review of the literature. Minerva, 47(1), 93-114.

Giannopoulou, E., Barlatier, P.-J. \& Pénin, J. (2019). Same but different? Research and technology organizations, universities and the innovation activities of firms. Research Policy, 48(1), 223233.

Goel, R. K., Göktepe-Hultén, D. \& Grimpe, C. (2017). Who instigates university-industry collaborations? University scientists versus firm employees. Small Business Economics, 48(3), 503-524.

Gulbrandsen, M. \& Thune, T. (2017). The effects of non-academic work experience on external interaction and research performance. The Journal of Technology Transfer, 42(4), 795-813. 
Hall, B. H. (2004). University-industry research partnerships in the United States.

Hansen, I.-E., Mork, O. J. \& Welo, T. (2018). Towards a Framework for Managing Knowledge Integration in University-Industry Collaboration Projects. Paper presented at the European Conference on Knowledge Management, 994-XIX.

Huang, M.-H. \& Chen, D.-Z. (2017). How can academic innovation performance in universityindustry collaboration be improved? Technological Forecasting and Social Change, 123, 210-215.

Hue Kyung, L., Hyun Duk, Y., Si Jeoung, K. \& Yoon Kyo, S. (2016). Factors affecting universityindustry cooperation performance: Study of the mediating effects of government and enterprise support. Journal of Science and Technology Policy Management, 7(2), 233-254.

Ishengoma, E. \& Vaaland, T. I. (2016). Can university-industry linkages stimulate student employability? Education + Training, 58(1), 18-44.

Ivascu, L., Cirjaliu, B. \& Draghici, A. (2016). Business model for the university-industry collaboration in open innovation. Procedia Economics and Finance, 39, 674-678.

Jackson, D. J. (2011). What is an innovation ecosystem. National Science Foundation, 1.

Kruss, G. \& Visser, M. (2017). Putting university-industry interaction into perspective: a differentiated view from inside South African universities. The Journal of Technology Transfer, 42(4), 884-908.

Lam, A. (2010). From 'ivory tower traditionalists' to 'entrepreneurial scientists'? Academic scientists in fuzzy university-industry boundaries. Social studies of science, 40(2), 307-340.

Lašáková, A., Bajzíková, L. \& Dedze, I. (2017). Barriers and drivers of innovation in higher education: Case study-based evidence across ten European universities. International Journal of Educational Development, 55, 69-79.

Leydesdorff, L., Etzkowitz, H., Ivanova, I. \& Meyer, M. (2017). The measurement of synergy in innovation systems: Redundancy generation in a triple helix of university-industrygovernment relations. Springer handbook of science and technology indicators. Heidelberg: Springer. Google Scholar.

Li, R. \& Fang, W. (2019). University-industry-government relations of the Ministry of Industry and Information Technology (MIIT) universities: The perspective of the mutual information. PloS one, 14(2), e0211939.

Lind, F., Styhre, A. \& Aaboen, L. (2013). Exploring university-industry collaboration in research centres. European Journal of Innovation Management, 16(1), 70-91.

Liu, A. M., Liang, O. X., Tuuli, M. \& Chan, I. (2018). Role of government funding in fostering collaboration between knowledge-based organizations: Evidence from the solar PV industry in China. Energy Exploration \& Exploitation, 36(3), 509-534.

Lotman, J. (2009). Culture and explosion (Vol. 1): Walter de Gruyter.

Mäkimattila, M., Junell, T. \& Rantala, T. (2015). Developing collaboration structures for university-industry interaction and innovations. European Journal of Innovation Management, $18(4), 451-470$.

Mascarenhas, C., Ferreira, J. J. \& Marques, C. (2018). University-industry cooperation: A systematic literature review and research agenda. Science and Public Policy, 45(5), 708-718.

Ministry of Development, P. A. S. (2018). Qatar National Development Strategy 2018-2022. Doha: Ministry of Development, Planning and Statistics. (P. a. S. Ministry of Development o. Document Number). 
Mitchell, T. R. (1982). Motivation: New directions for theory, research, and practice. Academy of management review, 7(1), 80-88.

Muscio, A., Quaglione, D. \& Scarpinato, M. (2012). The effects of universities' proximity to industrial districts on university-industry collaboration. China Economic Review, 23(3), 639650.

OECD. (2002). Frascati Manual: Proposed Standard Practice for Surveys on Research and Experimental Development (6 ed.). Paris: OECD.

Paavola, S. \& Hakkarainen, K. (2005). The knowledge creation metaphor-An emergent epistemological approach to learning. Science \& education, 14(6), 535-557.

Perkmann, M., Neely, A. \& Walsh, K. (2011). How should firms evaluate success in universityindustry alliances? A performance measurement system. R\&D Management, 41(2), 202-216.

Perkmann, M., Tartari, V., McKelvey, M., Autio, E., Broström, A., \& D’Este, P. et al. (2013). Academic engagement and commercialisation: A review of the literature on universityindustry relations. Research policy, 42(2), 423-442.

Planning, G. S. f. D. (2008). The Qatar National Vision 2030. Retrieved 04 August 2018 from https://www.mdps.gov.qa/en/knowledge/HomePagePublications/QNV2030_Arabic_v2.pdf.

Rajalo, S. \& Vadi, M. (2017). University-industry innovation collaboration: Reconceptualization. Technovation, 62, 42-54.

Rau, C., Neyer, A.-K. \& Möslein, K. M. (2012). Innovation practices and their boundarycrossing mechanisms: a review and proposals for the future. Technology Analysis \& Strategic Management, 24(2), 181-217.

Rossi, F. (2010). The governance of university-industry knowledge transfer. European Journal of Innovation Management, 13(2), 155-171.

Rossi, F. \& Rosli, A. (2013). Indicators of university-industry knowledge transfer performance and their implications for universities: Evidence from the UK's HE-BCI survey.

Rothaermel, F. T., Agung, S. D. \& Jiang, L. (2007). University entrepreneurship: a taxonomy of the literature. Industrial and corporate change, 16(4), 691-791.

Salehi, N. (2013). Mediating Effect of Absorptive Capacity on the Relationship Between Antecedents, Research and Development and Innovation. University Technology Malaysia Johor Bahru.

Salleh, M. \& Omar, M. (2013). University-industry collaboration models in Malaysia. ProcediaSocial and Behavioral Sciences, 102, 654-664.

Saunders, M. N. \& Lewis, P. (2012). Doing research in business \& management: An essential guide to planning your project: Pearson.

Scandura, A. (2016). University-industry collaboration and firms' R\&D effort. Research Policy, 45(9), 1907-1922.

Seppo, M. \& Lilles, A. (2012). Indicators measuring university-industry cooperation. Discussions on Estonian Economic Policy, 20(1), 204.

Son, H., Chung, Y. \& Hwang, H. (2019). Do technology entrepreneurship and external relationships always promote technology transfer? Evidence from Korean public research organizations. Technovation, 82, 1-15.

Striukova, L. \& Rayna, T. (2015). University-industry knowledge exchange: An exploratory study of Open Innovation in UK universities. European Journal of Innovation Management, 18(4), 471-492. 
Vaaland, T. I. \& Ishengoma, E. (2016). University-industry linkages in developing countries: perceived effect on innovation. Education + Training, 58(9), 1014-1040.

Van Looy, B., Ranga, M., Callaert, J., Debackere, K. \& Zimmermann, E. (2004). Combining entrepreneurial and scientific performance in academia: towards a compounded and reciprocal Matthew-effect? Research Policy, 33(3), 425-441.

Villani, E., Rasmussen, E. \& Grimaldi, R. (2017). How intermediary organizations facilitate university-industry technology transfer: A proximity approach. Technological Forecasting and Social Change, 114, 86-102.

Yalçıntaş, M., Kaya, C. Ç. \& Kaya, B. (2015). University-industry cooperation interfaces in Turkey from academicians' perspective. Procedia-Social and Behavioral Sciences, 195, 6271.

Zahra, S. A. \& George, G. (2002). Absorptive capacity: A review, reconceptualization, and extension. Academy of management review, 27(2), 185-203.

Zhang, Y., Chen, K. \& Fu, X. (2019). Scientific effects of Triple Helix interactions among research institutes, industries and universities. Technovation. 